\title{
Creativity in Higher Education: Challenges and Facilitating Factors
}

\author{
Eunice M. L. Soriano de Alencar ${ }^{1}$ \\ Denise de Souza Fleith \\ Universidade de Brasília, Brasília, Brazil \\ Nielsen Pereira \\ Purdue University, West Lafayette, USA
}

\begin{abstract}
The importance of fostering student creativity in higher education has been widely recognized, due to the need for preparing young people for the uncertain and complex world of work, which requires individuals to be able to use their creative abilities. Despite this recognition, the encouragement of creativity in higher education has been a challenge for faculty. Although there is agreement that college students should be creative, college faculty are generally not familiar with learning and teaching environments that promote creativity. Furthermore, many factors impact creativity expression in higher education institutions, such as students' resistance, organizational structure of universities, faculty attributes and pedagogical practices. This article addresses various challenges to creativity blooming in higher education, as well as some factors that facilitate its nurturance in this type of educational setting.
\end{abstract}

Keywords: Creativity, higher education, faculty, students, pedagogical practices.

\section{Criatividade na Educação Superior: Desafios e Fatores Facilitadores}

\section{Resumo}

A importância de se estimular a criatividade de estudantes da educação superior tem sido amplamente reconhecida devido à necessidade de preparar os jovens para o mundo incerto e complexo do trabalho, que requer dos indivíduos habilidade para utilizar suas capacidades criativas. Apesar desse reconhecimento, o incentivo à criatividade na educação superior tem se constituído um desafio para os professores. Embora haja consenso de que os estudantes universitários sejam criativos, os professores, em geral, não estão familiarizados com ambientes de ensino-aprendizagem promotores da criatividade. Além disso, muitos fatores impactam a expressão criativa em instituições de ensino superior, tais como resistência dos estudantes, estrutura organizacional das universidades, atributos dos professores e práticas pedagógicas. Este artigo discute vários desafios ao florescimento da criatividade na educação superior, bem como alguns fatores que facilitam seu desenvolvimento nesse tipo de contexto educativo.

Palavras-chave: Criatividade, educação superior, professores, estudantes, práticas pedagógicas.

1 Mailing address: Universidade de Brasília, Instituto de Psicologia, Campus Darcy Ribeiro, Brasília, DF, Brazil 70910-900. Phone: (61) 3107-6888. E-mail: eunices.alencar@gmail.com 


\section{La Creatividad in la Educación Superior: Desafíos y Factores Facilitadores}

\section{Resumen}

La importancia de fomentar la creatividad de los estudiantes en la educación superior ha sido ampliamente reconocida, debido a la necesidad de preparar a los jóvenes para el mundo incierto y complejo del trabajo, que requiere que los individuos sean capaces de utilizar sus capacidades creativas. A pesar de este reconocimiento, el fomento de la creatividad en la educación superior ha sido un desafío para el profesorado. Aunque hay acuerdo en que los estudiantes universitarios deben ser creativos, los profesores universitarios, en general, no están familiarizados con los entornos de aprendizaje y enseñanza que promueven la creatividad. Además, muchos factores afectan la expresión creativa en las instituciones de educación superior, por ejemplo la resistencia de los estudiantes, la estructura organizativa de las universidades, los atributos de los profesores y prácticas pedagógicas. Este artículo aborda varios desafíos para el florescimiento de la creatividad en la educación superior, así como algunos factores que facilitan su desarollo en este tipo de entorno educativo.

Palabras clave: Creatividad, educación superior, profesores, estudiantes, prácticas pedagógicas.

The importance of creativity has been increasingly recognized by scholars and professionals from various fields (e.g., Davis, 2004; Robinson, 2013). Research on creativity development reminds us that, in contemporary society, those who do not make use of their ability to create are at risk of failure in one or more facets of life (Bresnahan, 2013; Crainer \& Dearlove, 2014; Kaufman \& Sternberg, 2010). Csikszentmihalyi (2007) highlights that, while in the Renaissance creativity could be a luxury for some, at present, it is a necessity for our survival. Creativity helps individuals to take better advantage of opportunities and to respond more productively to the challenges and difficulties in their personal and professional lives. Creative behaviors also contribute to the quality of life, as their expression is usually accompanied by feelings of satisfaction and pleasure, which are fundamental elements of emotional welfare and mental health (Alencar, 2007; De Breu, Baas, \& Nijstad, 2012; Pannells \& Claxton, 2008; Runco, 2004).

Creativity is also of foremost importance in the business world, being an essential factor for innovation and the consequent success of organizations (Bruno-Faria, Vargas, \& Martínez, 2013). Creativity has been regarded as a critical element for the survival of many corporations, due to the challenges generated by globalization, increasing competition, and rapid pace of change. This scenario forces organizations to innovate more quickly, which requires more efficient use of human resources, including the employees' creativity.

The relevance of creativity to society is also unquestionable. As pointed out by SmithBingham (2007), the future prosperity of countries increasingly depends on their ability to innovate, transform ideas into new products and services, develop new technologies and forms of production, introduce products and services in new markets and, in the global context, address the numerous challenges in the areas of health, education, and work. Similarly, Lubart (2007) stresses that, "in respect to the capital issues, such as those of the social or planetarium equilibrium, the need of new approaches and solutions becomes increasingly urgent" (p. 8).

The awareness of the relevance of creativity has led governments of several countries to create educational initiatives with the purpose of promoting a debate and an implementation of educational policies aimed at the development of students' creative abilities. According to Cheung, Roskams, and Fisher (2006), for example, providing opportunities for creativity training has become a crucial part of university 
education in Hong Kong, in line with the Hong Kong Government's expectation that higher education must promote flexible, creative, and critical students. Smith-Bingham (2007) discusses the renewed interest in creativity in Great Britain, describing projects and initiatives in that direction and some challenges that those responsible for the production of public policy have come across to make creativity a political priority. Recommendations for promoting creativity in university curricula have been made by governments of countries such as China and Japan, as well as by American and European business leaders (Strom \& Strom, 2002).

To justify the importance of fostering creativity in higher education, Jackson (2006) stated that if "the purpose of higher education is to help students develop their potential as fully as possible at this level, then enabling students to be creative should be an explicit part of their higher education experience" (p. 1). Jackson also emphasizes that higher education needs to take into account the important role of creativity in the process of preparing young people for the uncertain and complex world of work, which requires employees to be able to make use of their creative abilities. Jackson (2006), as well as Alencar and Fleith (2010), Jackson, Oliver, Shaw, and Wisdom (2007), and Romo (2012), call attention to the essential role of creativity in the knowledge society. For these reasons, university faculty should promote conditions, including strategies, approaches, methods, and instruction addressing the development of students' creative ability. This was one of the factors that led the European University Association to carry out the project Creativity in Higher Education, with the participation of representatives from forty-two higher-education institutions from 21 different countries (i.e., two institutions per country), who were invited to participate in the project. The purpose of this project was to analyze conditions that could promote or inhibit creativity at the university setting, with a focus on various topics, such as innovation in teaching and learning, and structure and leadership of higher education institutions (European University Association, 2007).

\section{Challenges to Creativity Blooming in Higher Education}

Despite the recognition of the benefits of creativity for individuals and their personal achievement as well as for society, with the exception of isolated initiatives in some countries, the development of creativity is not a priority in education. Creative abilities are often repressed not only in elementary and secondary education (Alencar, 2007; Bermejo, Ruiz, Prieto, Ferrándiz, \& Sainz, 2015; Pfeiffer \& Wechsler, 2013; Renzulli, 2005; Runco, 2004), but also in higher education (Alencar \& Fleith, 2010; Cropley, 2005; Gibson, 2010; Hosseini, 2011; Nakano \& Wechsler, 2006; Wechsler \& Nakano, 2011). Empirical evidence suggests that the creativity of the individual declines with increasing years of formal education, with various authors underscoring limited opportunities and even the discouragement and punishment of the expression of creativity in higher education (Alencar \& Fleith, 2009; Castanho, 2000; Csikszentmihalyi, 2007; Wechsler, 2001, 2002). Cropley (2005), for example, concluded that Australian universities, have not provided the necessary training for students to master effective strategies to face new situations, to cope with rapid change, and to deal with unpredictable problems, since $75 \%$ of all recent graduates, regardless of their discipline of study, were being considered by employers who deemed them as unsuitable for employment, due to deficiencies in creativity, problem solving, and critical and independent thinking. Along the same line, Gilson (2008) refers to an article published in The Economist, in which it is pointed out that "the biggest challenge facing organizations today is not finding or hiring cheap workers, but rather hiring individuals with brainpower (both natural and trained) and especially the ability to think creatively" (p. 304). These examples suggest that creativity has often been neglected in educational systems.

The lack of attention to the development of creative abilities of college students has been discussed by several authors, such as Alencar and Fleith (2009), Castanho (2000), Csikszentmihalyi (2007), Jackson (2006, 
2007), Jackson et al. (2007) and Wechsler (2001). According to Jackson et al. (2007), the importance of creativity in teaching and learning processes has been widely underestimated in the context of higher education, since higher education institutions tend to give more value to critical thinking. Such point of view is in line with Fryer (2007), who also signaled that creativity did not get the necessary recognition, being undervalued in a large number of disciplines taught in universities in England. Castanho (2000) also observed lack of interest in promoting creativity in university courses, underscoring that in Brazilian universities creativity receives little to no attention. Likewise, Hosseini (2011) discussed the tendency of university faculty in Iran to rely on educational practices that reduce student motivation and creativity. The attitudes and resistance of faculty and students; organizational elements of structural, cultural and procedural nature; time and other resources; and government policies were considered as potential barriers to the flourishing of creativity in higher education by Jackson (2006). Jackson points out that, although students are often expected to be creative, creativity is rarely included in the syllabi of higher education courses as an explicit learning objective. In addition, Jackson calls attention to the limited knowledge of creative approaches to teaching by many university faculty, who are also unfamiliar with the literature on how to foster creativity in educational settings. Furthermore, the dominance of convergent teaching practices with emphasis on the transmission of knowledge prevails, as Csikszentmihalyi (2007) points out:

Schools teach how to answer, not to question. They teach isolated disciplines that, as the years pass, become more and more difficult to integrate. Reference to the present, let alone to the future, is lacking in most school curricula which are dominated... by a concern with transmitting past knowledge. (p. xix) Obstacles to the promotion of creativity in higher education were investigated by Fryer (2007), Alencar and Fleith (2010), and Lima and Alencar (2014). Fryer (2007), analyzed the answers of 90 teachers to an email questionnaire and noted that excessive work load, not enough time to prepare lessons, large class sizes, insufficient time for contact with students, and inadequate resources were factors considered by the participants of the study as elements that restrict the expression of creativity in higher education. Alencar and Fleith (2010) examined university instructors' perceptions of obstacles to the development and expression of student creativity in their classrooms. Three-hundred and thirty-eight university instructors completed a checklist of obstacles to the promotion of creativity in the classroom. Results revealed that student-related factors, such as students with learning difficulties, lack of interest in the content taught, and number of students in the classroom, followed by few opportunities to discuss and exchange ideas with colleagues about instructional strategies, and high number of disciplines and other activities under their responsibility, limiting the time of preparation for teaching, were among the most frequent obstacles. Lima and Alencar (2014) examined factors that hinder the promotion of the creative expression in graduate courses according to 15 professors who were interviewed about their pedagogical practices and factors that restrict the development and expression of graduate students' creativity. The impediment factors most frequently pointed out were related to: (a) the students (internalization of a culture of conformity and of knowledge reproduction; fear of making mistakes; conformity; resistance to innovating teaching procedures; fear of expressing new ideas); (b) the professors (lack of time and excessive workload; lack of knowledge on creativity and how to nurture it in the students; fear of innovating; lack of incentive by the university system); and (c) the higher education institution (omission in relation to creativity; requirement of a heavy workload; bureaucracy).

One factor that has been discussed in the literature to explain the limited use of strategies to cultivate creativity in the higher education classrooms is instructors' own previous schooling experiences. Beghetto (2010) highlights that this prior experience as a student has a profound 
influence on the beliefs, knowledge, and instructional practices of teaching. The tendency is to reproduce in the classroom the pedagogical practices teachers experienced as a student. In the same line, Martínez (2002) observed that creativity and how to foster it in the students are rarely included in academic projects and teacher education curricula. This is in agreement with results obtained by Lima and Alencar (2014) and Oliveira and Alencar (2014) in studies conducted with university professors. These professors, when asked if creativity had been a theme addressed in their previous schooling, all responded negatively, although some of the professors interviewed by Oliveira and Alencar (2014) informed that they were encouraged to express their creativity.

With regard to creativity measures in higher education, the Inventory of Teachers' Practices for Creativity in Higher Education (Alencar \& Fleith, 2014) was especially designed to assess the extent to which teaching practices are fostering creativity at the university level based on students' perception. The instrument measures four factors associated with the classroom climate for creativity: Incentive to New Ideas, Climate for Expression of Ideas, Assessment and Teaching Methodology, and Interest for Student's Learning. Reliability estimates for the four factors range from .85 to .91 . This instrument may be used as a tool for research as well as for evaluation of teaching behaviors and strategies implemented in the classroom, offering to professors feedback of their pedagogical practice as perceived by students. Alencar and Fleith (2004) asked college students from public and private institutions to evaluate the extent to which their professors presented behaviors in the classroom which fostered students' creative development and expression. The Assessment and Teaching Methodology was the factor with the lowest average. Female students evaluated their professors more favorably in the factors Incentive to New Ideas and Interest for Students' Learning, comparing to male students.

Ribeiro and Fleith (2007) conducted an investigation involving 1,396 university students. Advanced semesters students evaluated their professors' practices in relation to creativity more positively comparing to the students from the first semesters. Differences among private and public university students' perceptions of their professors' practices were also observed in the factors Incentive to New Ideas and Assessment and Teaching Methodology, being the private university students' perception more favorable.

\section{Creativity in Higher Education: Facilitating Factors}

To facilitate the nurturing of creativity in higher education, it is necessary the promotion of an institutional culture that gives greater value to creativity and its expression, not being restricted to traditional forms of academic development. In this sense, Wisdom (2007) discusses the need for a cultural change in higher education, including as one of its elements "to help teachers understand and enhance their own creativity and to recognize this as an integral part of their professionalism" (p. 183), as well as ensuring an institutional climate that encourages reflection and the personal development of both teachers and students.

Due to the important role of instructors in the development of students' creative potential, creativity should be a topic widely addressed in teacher professional development, to prepare teachers to recognize and develop students' creative abilities. It is also necessary for teachers to have access to information about pedagogical practices that can be used in the classroom to develop students' creativity as well as about the various factors that may influence creative expression.

To help university faculty establish conditions for the flourishing of creativity in higher education classrooms, Wisdom (2007) suggests, among others, the following strategies:

- Having sufficient time and space in the curriculum to allow students to develop their creativity.

- Having sufficiently varied and diverse working situations to enable all students to be creative. 
- Allowing students the freedom to work in new and interesting ways.

- Challenging students with real, demanding and exciting work.

- Designing assessment that allows for outcomes that are not narrowly pre-determined.

- Fostering a departmental climate that encourages reflection and personal development for both staff and students.

- Continuing academic debate within the discipline, and dialogue with the various stakeholders, about the nature of the subject and the role of creativity within it. (p. 193)

Other recommendations for promoting creativity outlined by authors, such as Alencar and Fleith, (2009), Cropley (2005, 2006), Fleith (2007), Martínez (2002), McCluskey (2013), and Wechsler (2001) are:

- Taking into account the students' previous knowledge.

- Reserving time for dialogue, listening to students with respect.

- Helping the students to get rid of emotional blocks, like fear of making mistakes and the fear of being criticized.

- Encouraging students to pursue topics that interest them most.

- Diversifying the teaching strategies used in the classroom.

- Exposing students only to constructive criticism.

- Encouraging students to express new ideas.

- Asking provocative questions.

- Maintaining a positive relationship with students.

- Promoting a psychologically safe environment, in which students are not afraid to expose themselves.

- Understanding individual differences concerning behaviors and problem solving skills.

Of particular importance is to facilitate the development of teachers' creativity during their own schooling process, especially during the years of teacher professional preparation. This should not be done by including one discipline on creativity in teacher preparation curricula, but through a truly creative teaching and learn- ing environment, in which the future teachers experience as students, what they can do later as teachers; and where they find ways for the expressing of their creative potential (Martínez, 2002; Romo \& Sanz, 2000).

\section{Concluding Remarks}

There are many challenges faced by higher education professors and students. One of them, which is discussed in this paper, concerns the need for the promotion of a pro-creativity culture, which stimulates the flourishing of creativity among teachers and students. This is especially relevant given that the prevailing models of teacher professional preparation are still deeply ingrained in a culture where educational opportunities for creative expression are still very limited. There are few opportunities for teachers to reflect, take part in dialogue, and discuss their pedagogical practices. Promoting classroom environments that ensure active learning and encourage students to make use of creativity in conjunction with other skills is one of the challenges for many university instructors. Additionally, programs for continued professional development for higher education faculty are virtually non-existent in many countries.

We hope this paper will contribute by drawing attention to the importance of creativity in higher education. This is a call for research focusing on: (a) university students' and professors' perceptions of the classroom climate for creativity; (b) the identification of educational practices that favor and inhibit students' creative expression; and (c) the impact of the implementation of creative teaching methods on students' achievement, creativity, self-concept, and motivation to learn. The contemporary world scenario is characterized by much turbulence, uncertainty, and instability, which requires educators to have the role of catalysts of students' creative potential. Although some professors are aware of the importance of creativity, much work needs to be done to ensure a higher education culture that supports and encourages creativity. 


\section{References}

Alencar, E. M. L. S. (2007). O papel da escola no desenvolvimento do talento criativo [The role of school in the development of the creative talent]. In D. S. Fleith \& E. M. L. S. Alencar (Eds.), Desenvolvimento de talentos e altas habilidades [Developing talents and high ability] (pp. 151162). Porto Alegre, RS: ArtMed.

Alencar, E. M. L. S., \& Fleith, D. S. (2004). Creativity in university courses: Perceptions of professors and students. Gifted and Talented International, 19(1), 24-28.

Alencar, E. M. L. S., \& Fleith, D. S. (2009). Criatividade. Múltiplas perspectivas [Creativity. Multiple perspectives]. Brasília, DF: Editora da Universidade de Brasília.

Alencar, E. M. L. S., \& Fleith, D. S. (2010). Criatividade na educação superior: Fatores inibidores [Creativity in higher education: Inhibiting factors]. Avaliação, 15(2), 201-206. doi:10.1590/ S1414-40772010000200011

Alencar, E. M. L. S., \& Fleith, D. S. (2014). Inventory of teaching practices for creativity in higher education. In E. M. L. S. Alencar, M. F. BrunoFaria, \& D. S. Fleith (Eds.), Theory and practice of creativity measurement (pp. 51-64). Waco, TX: Prufrock Press.

Beghetto, R. A. (2010). Creativity in the classroom. In J. C. K. Kaufman \& R. J. Sternberg (Eds.), The Cambridge handbook of creativity (pp. 447463). New York: Cambridge University Press.

Bermejo, R., Ruiz, M. J., Prieto, M. D., Ferrándiz, C., \& Sainz, M. (2015). Ensino do pensamento científico-criativo em estudantes do ensino médio [Teaching creative-scientific thinking in high school students]. In M. F. Morais, L. C. Miranda, \& S. M. Wechsler (Eds.), Criatividade. Aplicações práticas em contextos internacionais [Creativity. Practical applications in international contexts] (pp. 109-136). São Paulo, SP: Vetor.

Bresnahan, T. F. (2013). Entrepreneurial creativity. In A. Robinson (Ed.), Exceptional creativity in science and technology (pp. 163-189). West Conshohocken, PA: Templeton Press.

Bruno-Faria, M. F., Vargas, E. R., \& Martínez, A. M. (Eds.). (2013). Criatividade e inovação nas organizações. Desafios para a competitividade [Creativity and innovation in organizations.
Challenges for competitiveness]. São Paulo, SP: Atlas.

Castanho, M. E. L. M. (2000). A criatividade na sala de aula universitária [Creativity in the university classroom]. In I. P. A. Veiga \& M. E. L. M. Castanho (Eds.), Pedagogia universitária. A aula em foco [University pedagogy. Focusing the classroom] (pp. 75-89). Campinas, SP: Papirus.

Cheung, C., Roskams, T, \& Fisher, D. (2006). Enhancement of creativity through a semester course in university. The Journal of Creative Behavior, 40(1), 1-26. doi:10.1002/j.2162-6057.2006. tb01264.x

Crainer, S., \& Dearlove, D. (2014). Future thinkers. New thinking on leadership, strategy, and innovation for the twenty-first century. New York: McGraw-Hill.

Cropley, A. J. (2005). Creativity in education \& learning. London: Routledge.

Cropley, A. J. (2006). Creativity: A social approach. Roeper Review, 28(3), 125-130. doi:10.1080/02783190609554351

Csikszentmihalyi, M. (2007). Developing creativity. In N. Jackson, M. Oliver, M. Shaw, \& J. Wisdom (Eds.), Developing creativity in higher education (pp. xviii-xx). London: Routledge.

Davis, G. (2004). Creativity is forever ( $5^{\text {th }}$ ed.). Dubuque, IA: Kendall Hunt.

De Breu, C. K. W., Baas, M., \& Nijstad, B. A. (2012). The emotive roots of creativity: Basic and applied issues on affect and motivation. In M. Mumford (Ed.), Handbook of organizational creativity (pp. 217-240). San Diego, CA: Elsevier.

European University Association. (2007). Report of the EUA Creativity Project 2006-2007. Brussels: Author.

Fleith, D. S. (2007). Como desenvolver a criatividade no contexto educacional [How to develop creativity in the educational context]. In Serviço Social da Indústria (Ed.), Criatividade [Creativity]. Brasília, DF: Serviço Social da Indústria.

Fryer, M. (2007). Facilitating creativity in higher education: A brief account of National Teaching Fellows' views. In N. Jackson, M. Oliver, M. Shaw, \& J. Wisdom (Eds.), Developing creativity in higher education (pp. 74-88). London: Routledge. 
Gibson, R. (2010). The 'art' of creative teaching: Implications for higher education. Teaching in Higher Education, 15(5), 607-613. doi: $10.1080 / 13562517.2010 .493349$

Gilson, L. L. (2008). Why be creative: A review of the practical outcomes associated with creativity at the individual, group, and organizational levels. In J. Zhou \& C. E. Shalley (Eds.), Handbook of organizational creativity (pp. 303-322). New York: Lawrence Erlbaum.

Hosseini, A. (2011). University student's evaluation of creative education in universities and their impact on their learning. Procedia - Social and Behavioural Sciences, 15, 1806-1812. doi:10.1016/j.sbspro.2011.04.007

Jackson, N. (2006). Creativity in higher education. Creating tipping points for cultural change. SCEPTrE Scholarly Paper, 3(1), 1-25.

Jackson, N. (2007). Imagining a different world. In N. Jackson, M. Oliver, M. Shaw, \& J. Wisdom (Eds.), Developing creativity in higher education (pp. 1-19). London: Routledge.

Jackson, N., Oliver, M., Shaw, M., \& Wisdom, J. (Eds.). (2007). Developing creativity in higher education. London: Routledge.

Kaufman, J. C., \& Sternberg, R. J. (2010). Preface. In J. C. Kaufman \& R. J. Sternberg (Eds.), The Cambridge handbook of creativity (pp. xiii-xv). New York: Cambridge University Press.

Lima, V. B. F., \& Alencar, E. M. L. S. (2014). Criatividade em programas de pós-graduação em educação: Práticas pedagógicas e fatores inibidores [Creativity in graduate programs in education: Pedagogical practices and inhibiting factors]. Revista Psico USF, 19(1), 61-72. doi:10.1590/S1413-82712014000100007

Lubart, T. (2007). Psicologia da criatividade [Psychology of creativity]. Porto Alegre, RS: ArtMed.

Martínez, A. M. (2002). A criatividade na escola Três direções de trabalho [Creativity in school: Three work directions]. Linhas Críticas, 8(15), 189-206.

McCluskey, K. W. (2013). Thoughts about tone, educational leadership, and building creative climates in our schools ( $2^{\text {nd }}$ ed.). Ulm, Germany: ICIE.

Nakano, T., \& Wechsler, S. M. (2006). O percurso da criatividade figural do ensino médio ao en- sino superior [The route of creativity from high school to higher education]. Boletim de Psicologia, 56(125), 205-219.

Oliveira, Z. M. F., \& Alencar M. L. S. (2014). Criatividade na pós-graduação stricto sensu: Uma presença possível e necessária [Creativity in graduate courses: A possible and necessary presence]. Revista de Educação Pública, 23(52), 53-75.

Pannells, T. C., \& Claxton, A. F. (2008). Happiness, creative ideation, and locus of control. Creativity Research Journal, 20(1), 67-71.

Pfeiffer, S. I., \& Wechsler, S. M. (2013). Youth leadership: A proposal for identifying and developing creativity and giftedness. Estudos de Psicologia (Campinas), 30(2), 219-229. doi:10.1590/S0103-166X2013000200008

Renzulli, J. (2005). Neglecting creativity. Education Week, 24, 31-32, 40.

Ribeiro, R. A., \& Fleith, D. S. (2007). O estímulo à criatividade em cursos de licenciatura [The incentive to creativity in training teachers' courses]. Paidéia (Ribeirão Preto), 17(38), 413416. doi:10.1590/S0103-863X2007000300010

Robinson, A. (Ed). (2013). Exceptional creativity in science and technology. West Conshohoken, PA: Templeton Press.

Romo, M. (2012). Psicología de la creatividad [Psychology of creativity]. Barcelona, España: Paidós.

Romo, M., \& Sanz, S. (2000). Primer encuentro estatal de docents e investigadores universitarios en creatividad [First state meeting of university professors and researchers in creativity]. Arte, Individuo y Sociedad, 12(1), 343-347.

Runco, M. A. (2004). Creativity. Annual Review of Psychology, 55(1), 657-687. doi:10.1146/ annurev.psych.55.090902.141502

Smith-Bingham, R. (2007). Public policy, innovation and the need for creativity. In N. Jackson, M. Oliver, M. Shaw, \& J. Wisdom (Eds.), Developing creativity in higher education (pp. 10-18). London: Routledge.

Strom, R. D., \& Strom, P. S. (2002). Changing the rules: Education for creative thinking. The Journal of Creative Behavior, 36(3), 183-200. doi:10.1002/j.2162-6057.2002.tb01063.x

Wechsler, S. M. (2001). A educação criativa: Possibilidades para descobertas [Creative education: 
Possibilities for discoveries]. In S. Castanho \& M. E. Castanho (Eds.), Temas e textos em metodologias do ensino superior [Themes and topics in higher education methodologies] (pp. 165-170). Campinas, SP: Papirus.

Wechsler, S. M. (2002). Criatividade e desempenho escolar: Uma síntese necessária [Creativity and school achievement: A necessary sinthesis]. Linhas Críticas, 8(15), 179-188.

Wechsler, S. M., \& Nakano, T. C. (Eds.). (2011). Criatividade no ensino superior: Uma perspectiva internacional [Creativity in the higher education: An international perspective]. São Paulo, SP: Vetor
Wisdom, J. (2007). Developing higher education teachers to teach creatively. In N. Jackson, M. Oliver, M. Shaw, \& J. Wisdom (Eds.), Developing creativity in higher education (pp. 183-196). London: Routledge.
Recebido: 12/01/2016

$1^{a}$ revisão: $29 / 03 / 2016$ Aceite final: $31 / 03 / 2016$ 